\title{
SPECIAL EFFECTS
}

Introduction: Elisabeth Jerichau-Baumann, "Egypt 1870"

JULIA KUEHN

Brogede Rejsebilleder (Motley Images of Travel) by Elisabeth Jerichau-Baumann, "Egypt 1870"

TRANSLATED BY RAGNHEIðUR ÓLAFSDÓTTIR 


\title{
ELISABETH JERICHAU-BAUMANN, "EGYPT 1870"
}

\author{
By Julia Kuehn
}

ELISABETH BAUMANN WAS BORN in Warsaw in 1819 to a German mapmaker, Philip Adolph Baumann, and his German wife, Johanne Frederikke Reyer. ${ }^{1}$ Her early training took her to Berlin and, from 1838, to the Düsseldorf Academy of Art, a leading one in its day. According to Hans Christian Andersen, who would later write a biography of his friend Elisabeth, the famous German painter Peter von Cornelius much admired Baumann's paintings, and speaking of them he declared, "She is the only real man in the Düsseldorf school," which was doubtlessly meant as a compliment (see Andersen, qtd. in Von Folsach 83). In Düsseldorf, Baumann was influenced by the prevailing realist trend of the Academy but added to it an idealistic and sensuous quality that would become her distinctive mark. After the completion of her training in 1845, Baumann went to Rome where she met the Danish sculptor Jens Adolf Jerichau, one of the outstanding talents of his time, whom she married a year later. The couple settled in Denmark in 1849 (although Jerichau-Baumann kept a studio in Rome) as Jens Adolf became a professor at, and later President of, the Royal Danish Academy of Fine Arts.

In 1861, Elisabeth Jerichau-Baumann herself became a member of the Royal Academy, but with her German training and artistic idiom, she found it rather difficult to find a place among the Danish artistic elite. These were the most intense years of resurgent patriotism during the first Schleswig War (1848-51), and Jerichau-Baumann encountered considerable opposition in the art world whose main purpose was to protect the ideals of the so-called Danish Golden Age and the heritage of Christoffer Wilhelm Eckersberg, the "Father of Danish Painting." As late as 1880, the most important debate among Danish artists was their artistic relation to other European traditions and their fear of a German or French influence. The cosmopolitan Jerichau-Baumann, however, refused to be intimidated by the "Nationals."

Her patriotic epic paintings like the allegorical Denmark, 1851 did not bring her the artistic recognition she deserved, but they made her name and work more familiar to the Danish public, as did her portraits of such well-known people as Hans Christian Andersen and King Christian IX's Queen Louise and their children. In this context, Jerichau-Baumann struck up a friendship with Princess Alexandra, wife of the future British King Edward VII, forging a relationship that would help Jerichau-Baumann on her later travels and especially with the British public. Over the next two decades, Alexandra's letters of introduction gave 
Jerichau-Baumann access to many foreign royal and official households, and brought the painter closer to Queen Victoria and her subjects. Jerichau-Baumann's portrait of Alexandra, which she presented to Victoria in 1861 - the very year the Prince of Wales first met his future bride - is in the Royal Collection to this day.

Turning to Jerichau-Baumann's travels and to situate the travelogue "Egypt 1870": Due to the "European" quality of her work and perhaps also because of what many contemporaries considered her un-ladylike ambition to continue with her work even after the birth of nine children, Jerichau-Baumann remained a controversial figure in the Danish art world. Critics remained rather cool towards her - calling her passionate use of strong colours un-Danish and her style "saccharine" and "pathetic," which they considered characteristic of the Düsseldorf School (Von Folsach 83). In striking contrast, the British art press was inclined favourably towards the painter. Her 1852 London Bridgewater Gallery Exhibition caught royal attention and Queen Victoria subsequently invited Jerichau-Baumann to give a private presentation in Buckingham Palace. Here, Jerichau-Baumann duly presented a portrait of Hans Christian Andersen to the Queen - her best-known Danish association and supporter before Alexandra. Over the next decades, the British press remained impressed with Madame Jerichau's compositions and style which, they said, "seldom lack[ed] power" ("French and Flemish Exhibition" 194). The French poet, novelist and literary art critic Théophile Gautier even argued after Jerichau-Baumann's first participation in the Paris World Fair of 1867 that only three women in Europe "deserved the title of painter" - Rosa Bonheur, Henriette Browne, and Elisabeth Jerichau - and the British seemed to support this claim (qtd. in Steward 276). Given such praise, it is unsurprising that Jerichau would retain her European artistic connections, travel extensively outside Denmark, and find her viewers and buyers elsewhere.

Given the tepid response of the Danish public to her work, Jerichau-Baumann turned her attention to the broader European public. She began to paint in the Orientalist genre that was booming in nineteenth-century France, Great Britain, Germany, and the United States. Orientalist subject matter both suited her artistic temperament and appealed to a larger public than her earlier work. ${ }^{2}$ From the 1850 s forward she followed in the artistic footsteps of Jean Auguste Dominique Ingres, Jean-Léon Gérôme, and Eugène Delacroix, and alongside Orientalist painters like Frederick Leighton, John Frederick Lewis, Ludwig Deutsch, Gustav Bauernfeind, and Edwin Lord Weeks. Her new quest became to exploit her "European" aesthetic and critical acclaim and become a leading and popular female painter of Oriental images. Intense and more targeted journeys to "the East" followed the earlier 1850s pleasure trips with her husband in Persia, the Middle East and North Africa. In 1869-70 and 1874-75 Elisabeth Jerichau-Baumann - accompanied by one of her sons, as her husband's duties kept him at the Royal Academy - returned to specifically Turkey, Greece, and Egypt, the main sites for Orientalist motifs.

Jerichau-Baumann adapted her talent for portraiture to meet the growing demand for Oriental likeness both in the East and in Europe. Alexandra's introductions opened doors for the painter in the better circles of Athens, Constantinople, Smyrna, and Cairo where JerichauBaumann immortalized pashas, khedives and governors, sultanas, princesses, and odalisques. There were two aspects to her success. In the East Jerichau-Baumann became instrumental in popularising western portrait painting and its techniques in Islamic countries whose own tradition of miniature painting was two dimensional and did not use light reflexes and shade. In the West her subject matter gave her work cache. As a woman, Jerichau-Baumann was allowed access to the harems, which remained inaccessible to male Orientalists. Her special 
combination of skill and access was noted by the British Art Journal when it announced before the painter's 1869 trip to Stamboul: "Madame Jerichau, the accomplished Danish artist, whose works are well known and highly estimated in England ... is, it is said, about to visit Constantinople, commissioned to paint portraits of the ladies of the Sultan's harem. It will be difficult to overrate the interest of such series" ("Minor Topics" 382).

Commissioned Oriental portraits would remain with the buyer or sitter, but JerichauBaumann would always leave with more than remuneration, namely original character sketches or additional portraits of the respective sitters, which she could hone and then exhibit and sell to primarily British, French, or German buyers. Given such program, an exhibition in London's New Bond Street Gallery in 1871 featured, as an Art Journal review suggests, portraits of a variety of "eastern women" - Greek, Italian, Turkish, Egyptian:

\footnotetext{
We instance [Madame Jerichau's] portrait of the Queen of Greece, wherein appear the utmost delicacy of treatment and brilliancy of colour. It is a head and bust, very simple and without any type of royalty..."The Favourite of the Hareem," an oil picture, declares itself at once a veritable study from Oriental life. All attempts at the improvisation of Hareem beauty by painters and poets have been very wide of the truth, as we learn from this and all other genuine representations of socalled eastern beauty. There are several pictures of eastern women: what is most valuable in them is their indisputable nationality, which is brought forward without any modification or dalliance with conventional prettiness of feature. The subjects principally are of the size of life. "La Penserosa," a tambourine-girl of Italian characteristics, is resting in a reflective attitude, which, together with the expression of the face, sustains well the title... Again "Helena, a young maiden from Hymetos," affords evidence of independent thought. In this figure the artist might have yielded to the fascination of the Greek facial line supported by classic and Academic authority, but she proposes nothing less than a Helen of a type distinctly modern and individual. In the background is the eastern side of the Acropolis, and one of the thirteen pillars of the temple of Jupiter. There are also one or two female studies of Fellaheen, in which truth and genuine nationality prevail over poets' dreams of matchless houris and peerless Egyptian maids. ("The Works of Madame Jerichau" 165)
}

I will address the reviewer's foregrounding of Jerichau's realism in due time, but for now, let me introduce the travelogue and its eighth chapter, "Egypt 1870," which mentions and reproduces three of the paintings referred to. Jerichau-Baumann's one and only travelogue, Brogede Rejsebilleder or Motley Images of Travel, was published in 1881. It offers, as Jerichau's preface rightly announces, motley recollections of travels in Africa, the Middle East, and southern Europe, which the painter had, for the most part, undertaken in the 1870 s along with some descriptions which had already appeared in Danish journals. The descriptions of places and people are embellished with xylographs after Elisabeth JerichauBaumann's and her son Harald's work. ${ }^{3}$ The abovementioned Helena painting is referenced at the beginning of the Egypt chapter in an account of its near destruction. It was later exhibited in the salon of the Hôtel du Sphinx. It is not reproduced in Motley Images of Travel, but the two reproduced xylographs of portraits of Egyptian fellahin women, carrying water and selling pottery, are likely to be copies of the originals that were exhibited in London in 1871.

Jerichau-Baumann was enchanted with the native women she encountered on her travels, whether in Athens, Constantinople, Smyrna, St Petersburg, or Cairo, and she tried to represent them as faithfully as she could, with words and paintbrush - the access that her sex allowed 


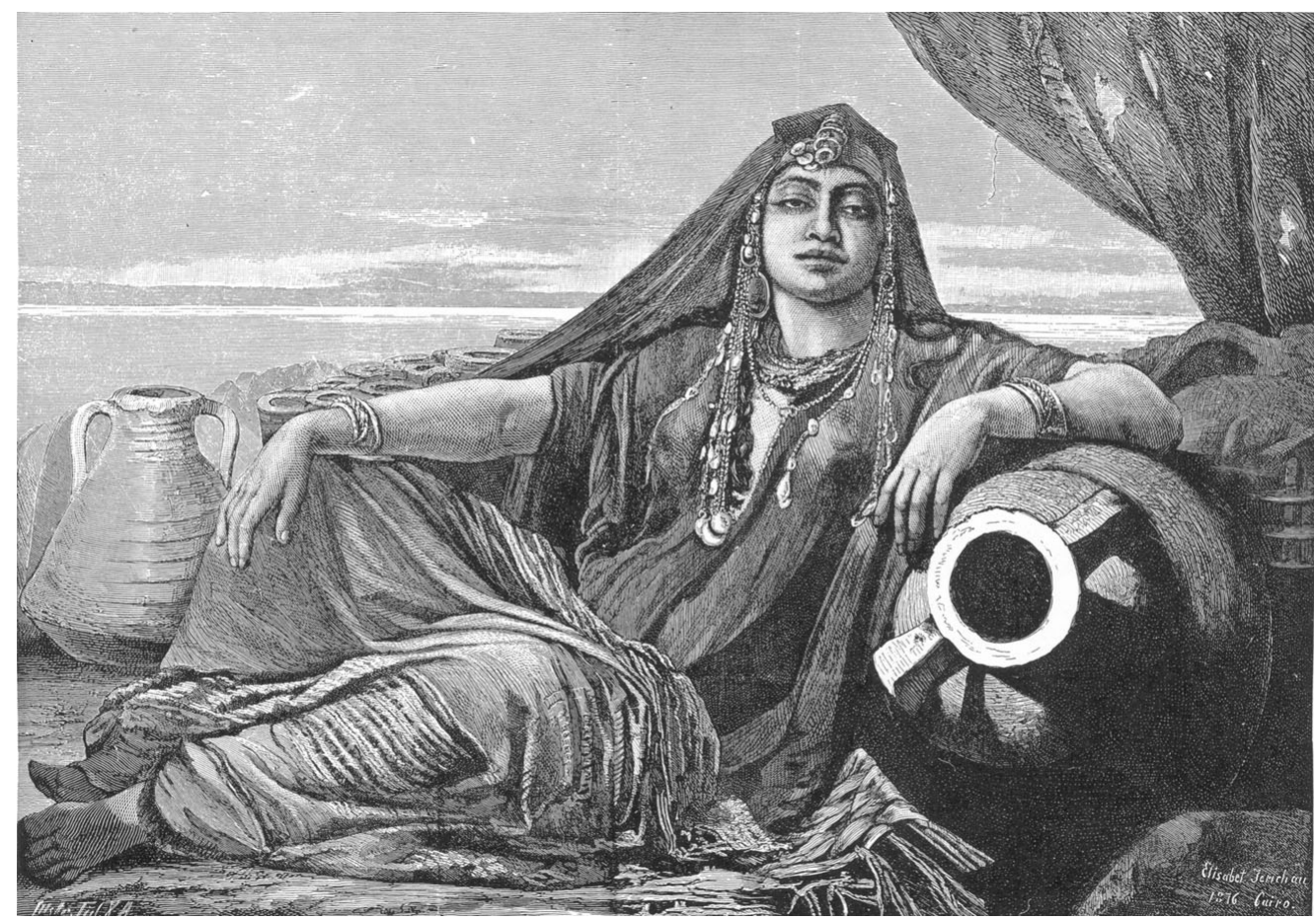

Figure 6. Elisabeth Jerichau-Baumann, "Pottery Seller." Xylograph, 1876, from Brogede Rejsebilleder [Motley Images of Travel] (Kjøbenhavn: Thieles, 1881), between 40-41.

her to the women of the Orient, whether these were payed sitters or unaware models, being both an advantage over her male counterparts and a responsibility.

Her Egypt chapter reveals her fascination with the women of Cairo, Bulak, Gizeh, and Memphis, whose exquisiteness she likened to that of a da Fiesole Madonna, and she especially celebrated the fact that these women seemed both unaware and unashamed of their beauty. Jerichau-Baumann saw pottery-selling women near Bulak; "a remarkable sight," as she writes. She sketched one of them, in typical fellahin shirt and headdress (Figure 6). On an excursion to Memphis and the Apis temple, Jerichau-Baumann observed fellahin women fetching water on the banks of the Nile, carrying the empty vessel on their head on their way towards the water source (Figure 7):

Sporadically, a single woman can be seen, walking soundlessly with her terracotta pot through the sandy fog towards the Nile. This is where I received the impression for my painting of the "Watercarrying woman by the Nile." One of the women let her transparent, black wrap fall for a moment, as it was very hot; she thought she would be unnoticed, and her body's full beauty became visible to me, intensified by the rich, ornamental, Nubian bride-belt, the only jewellery the husband is obliged to give his wife when he divorces her. 


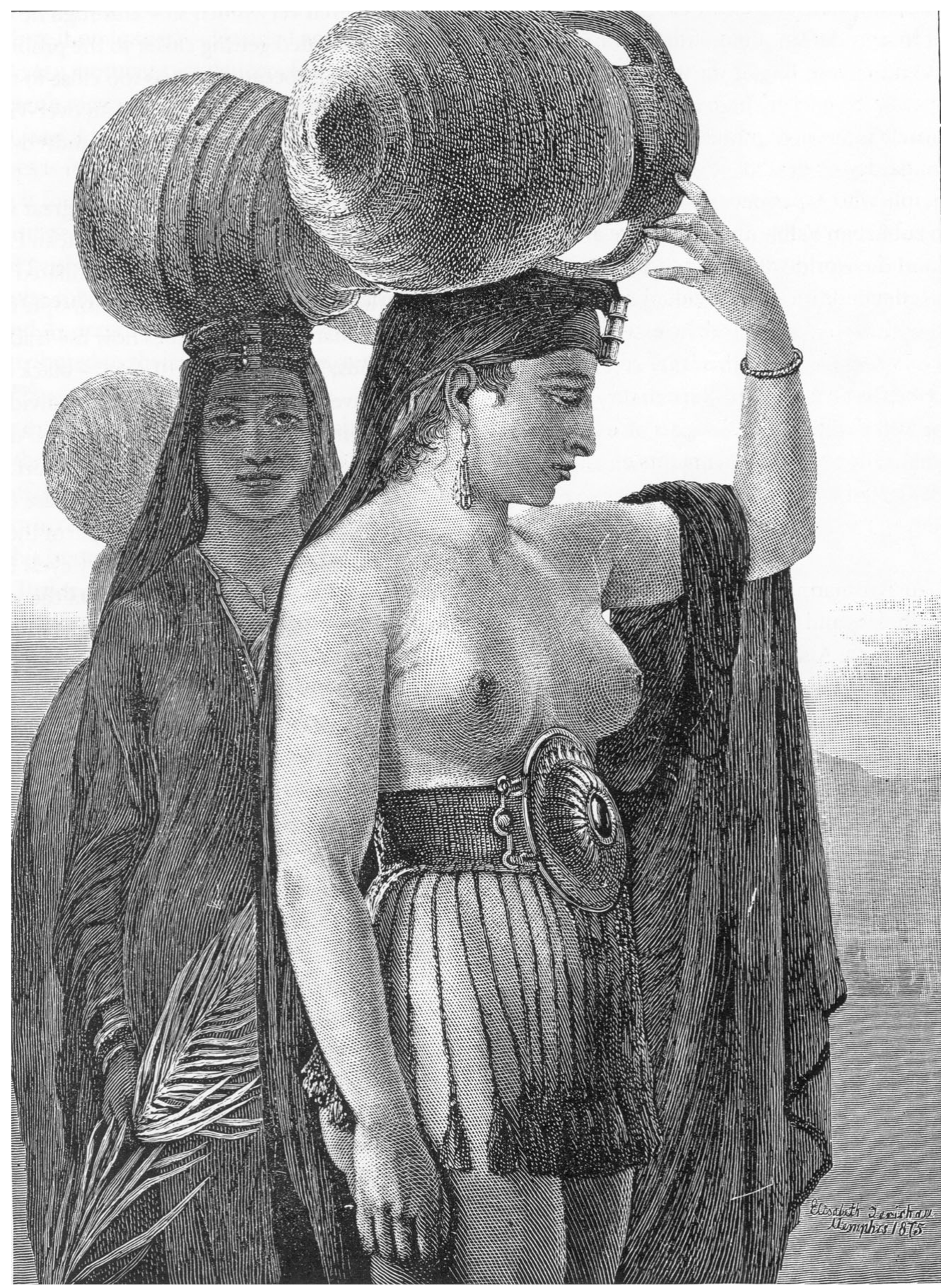

Figure 7. Elisabeth Jerichau-Baumann, "Water Carriers." Xylograph, 1875, from Brogede Rejsebilleder [Motley Images of Travel] (Kjøbenhavn: Thieles, 1881), opposite 40. 
A year after the trip, when Jerichau described to her son Harald the contents of her studio in Rome, she called one of the water carriers "the black lioness from the banks of the Nile" (Bøgh 209).

If critics like the Danish academy and the Art Journal reviewer thought of JerichauBaumann's paintings as realistic but at the same time "saccharine" and full of power and excitement, her travelogue, too, hovers in the uncertain space between documentation and imagination. Mary Wortley Montagu knew and addressed this problem more than a century earlier, when she wrote in her Turkish Embassy Letters: "We travellers are in very hard circumstances. If we say nothing but what has been said before us we are dull and have observed nothing. If we tell anything new, we are laughed at as fabulous and romantic" (Montagu 118). Montagu's awareness that the painter or writer of Oriental motifs had to colour her canvas in a way that responded to two audience expectations - being believable and applying certain conventions and being innovative and entertaining - is remarkable. And it is this same dilemma between documentation and imagination, content and artistry that we perceive in Jerichau-Baumann's travelogue and portraits.

The travelogue is undoubtedly of interest for its historical anchoring in a period in Egypt that had just seen the opening of the Suez Canal and the building of Cairo's Royal Opera House at the order of Khedive Ismail in 1869; events both mentioned by JerichauBaumann. She also takes note of the French archaeologist Auguste Mariette Bey, author of the story that would eventually become Aida, the first opera to be performed at the new Opera house. It is also likely that the ball Jerichau-Baumann attended in Cairo was organised by the same Ismail who would notoriously, in 1875, sell his share of the Suez Canal to the British Government. Jerichau's desire for cultural authenticity can further be seen in her use of native expressions, such as fellahin, khitab, baksheesh, or dahabeeyahs. The titles of her paintings also take on a documentary, almost ethnographic, quality when individuals become racial types, as Reina Lewis argues, namely an Egyptian Water Carrier or Pottery Seller (Gendering Orientalism 100ff; "Women Orientalist Artists" 166ff). With such documentary, historical, and almost scientific agenda, recent critics have argued, the female painter Jerichau-Baumann could preserve her image as a respectable woman despite her occasional nudes that might otherwise have seemed transgressive, but as documentation could be accepted and even celebrated by a reviewer in the Art Journal.

However, if there is a quest for documentation, the travelogue - like the paintings also shows artistic license and a number of public-oriented strategies. Jerichau-Baumann's repeated shifts between the past and the present tense - "The cart stops in the narrow downhill lane, I pass a mosque, at the door of which a poor fellahin stretches out his hand for baksheesh" - aim to paint a more immediate visual scene for the enjoyment of the reader. Direct speech and exclamations are employed to further enliven descriptions. Heroism on the part of the painter and exaggerated surface details abound: Madame Jerichau's grand finale when she eventually departs from Africa with a hatbox filled with gold coins, which no antagonist was able to snatch from her, is a case in point. Similarly inflated, the depiction of the grand ball in the Khedive's palace - decorations, diamonds, food, and all - echoes scenes from The Arabian Nights rather than offering a rational, sober account. Such historical events displaying cultural difference are clearly also a "rich source of feminine fantasy" and directed at a European audience that enjoys such exoticism, aristocratic gossip, and spirit of adventure (Roberts, "Contested Terrains" 181). Some anecdotes are addressed to a primarily Danish audience, like the one about the man from Copenhagen who was either so 
important that no one wanted to offend him or such a fashion trendsetter that all other men felt obliged to also cut off buttons from their dinner jackets. Other references are aimed at a British, French, or German audience that understand allusions to Hyde and Regent's Park, tout comme chez nous, and Siebensachen, or they are designed to give Jerichau-Baumann's writing and painting a specifically cosmopolitan character. Critic Elisabeth Oxfeldt has in fact suggested that Nordic Orientalism never hinged on a simple binary system of self-other, home-away, but involved several other European players, specifically Paris but also London, through whose eyes the Danes experienced and represented the Orient (Oxfeldt 224-25).

With regard to Jerichau's responses to certain audience expectations, there is an anecdote that shows just how much Jerichau moved along the documentation-imagination axis when she painted, exhibited, and sold Oriental pictures. Water Carrier bears the place and date Memphis 1875. And truly, Jerichau was in Egypt at that time, on a second visit in 1874-75, but the events in "Egypt 1870" supposedly report events from the earlier journey of 1869-70. It seems that the painter merged events from two visits in 1869-70 and in 1874-75 into a single travel narrative, and the images were of the later date. Pottery Seller is dated "Cairo, 1876," but Jerichau had actually already left Egypt at the time. And, to make things even more complicated in terms of Jerichau's playing with truth and fiction, even more fascinating is the instance of the painting Pottery Seller near Gizeh, 1876-78, which is not part of the travelogue but clearly related to it (Figure 8).

This painting is obviously a revised version of the earlier, similar Pottery Seller (Figure 6), also representing a female fellahin woman clad in the typical dark blue shirt and surrounded by pots. But whereas the woman in the xylograph looks rather self-conscious, the one in the later painting seems younger, more beautiful, sweeter, and also more sexual in the way she directs her gaze up to the viewer and interlocks eyes. Self-consciousness here becomes a titillating audience-directed game of sensuality qua purity, manifest in the way the pottery seller uses her headscarf to cover her bosom - when Jerichau's travelogue actually spoke of the Egyptian women's unconscious beauty and the natural way they carried their nakedness. The second, reworked pottery seller is aware of the desire her body invokes in the viewer in the same way the many odalisques in the pictures of the aforementioned male European Orientalists are. Was the 1876-78 painting Jerichau's aesthetic, audience-motivated response to Europe's craze for this type of imaginative (rather than documentary) Orientalist art? This is clearly not an ethnographic ("national type") or documentary portrait, as the Art Journal reviewer would have put it, but a "fantasy painting," as Mary Roberts would call it ("Harem Portraiture" 86). Here, the actual Oriental motif turns into an imaginary art piece that addresses a western viewer's requests about what the Orient should be: this is Orientalism according to Edward Said's understanding.

Even more intriguing is a piece of information written on the back of the later, more sensuous Pottery Seller painting, which declares that it was exhibited in Milan's Esposizione Nazionale di Belle Arti, in 1881 under the surprising title La Favorita del Sultano Abdul Aziz. Abdul Aziz, who died in 1876, was an actual sultan in Constantinople when Jerichau first visited the city on the Bosporus, but why would this sultan let his favourite woman be painted as a poor pottery seller by the Nile? This was either a mix-up or a rather ingenious strategy on Jerichau-Baumann's part, to go to the Orient, paint or sketch Oriental women, and then produce copies or adaptations of these models for European viewers and buyers, who did not care or know enough about the difference between an Ottoman harem woman and an Egyptian fellahin woman on a floating boat on the Nile. As Mary Roberts writes, 


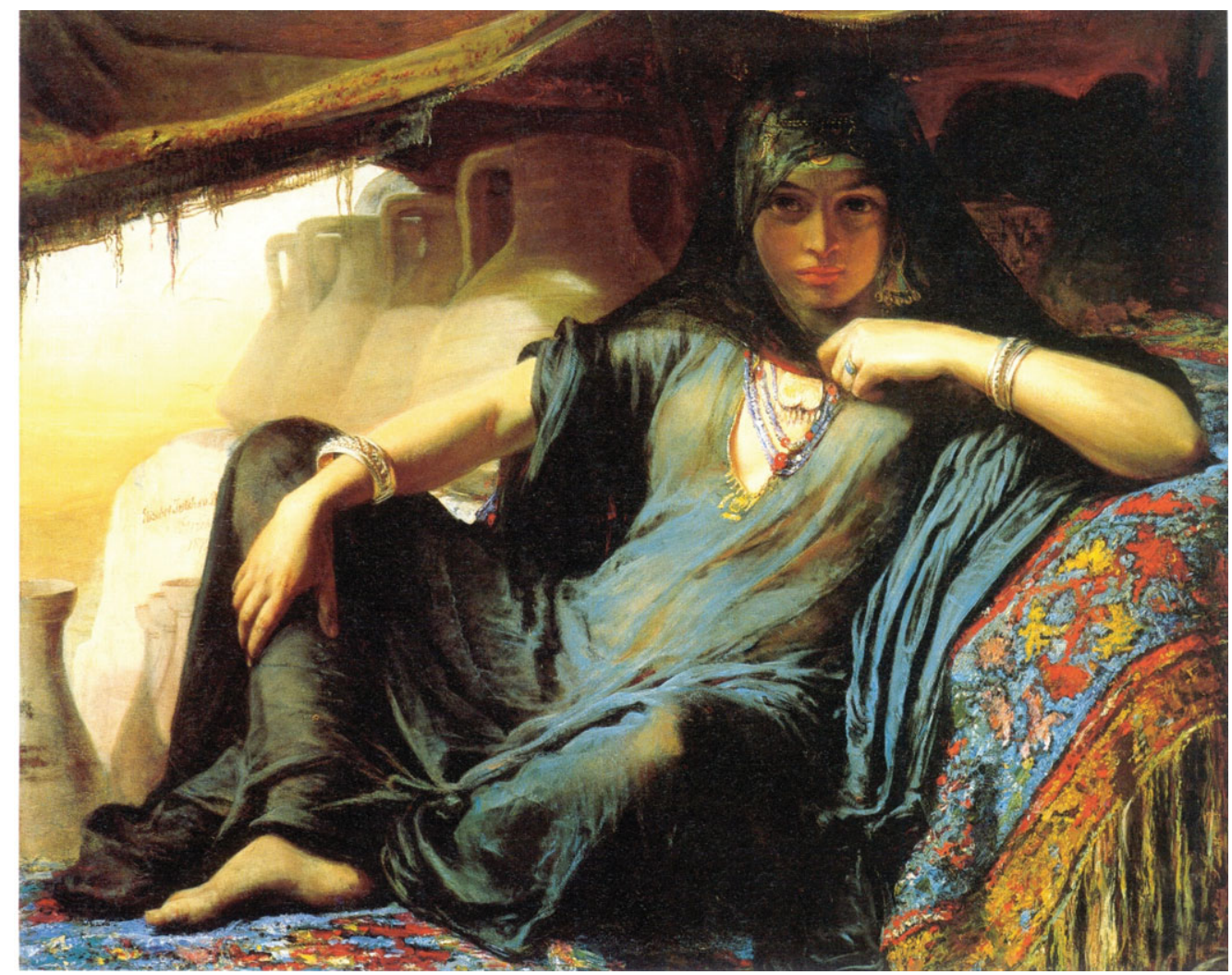

Figure 8. (Color online) Elisabeth Jerichau-Baumann, Pottery Seller near Gizeh. Oil on canvas, $1876-78$. Reproduced in Birgitte von Folsach, By the Light of the Crescent Moon: Images of the Near East in Danish Art and Literature, 1800-1875 (Copenhagen: David Collection, 1996), 88. Courtesy of the David Collection.

Jerichau-Baumann "was undeniably an ambitious painter with a strategic eye on the various requirements of the differing art markets in which she aimed to sell her work" ("Harem Portraiture" 86). As the painter wrote to her children in a letter from Rome on 1 April 1870:

I may go ... to London for two or three weeks in order to sell pictures. People - the nasty ones - say that I am not an artist but a commercial traveller. So be it! But who among the Danish artists can match me? I laugh in my beard, which, almost like Harald's, is beginning to grow, and let them prate. I know that all able people doff their hats to me, just as the able artists also do. Of this I have far too many proofs. (qtd. in Von Folsach 128)

This may have been Jerichau-Baumann's way to convince both herself and her children of her artistic merit, but it also clearly shows that Oriental painting or writing could not be thought of without a potential receiver, as Montagu had also suggested.

Elisabeth Jerichau-Baumann died in Copenhagen in 1881. While the leading artists' circles in Denmark kept her at arm's length throughout her career, her paintings now slowly resurface from museum storerooms and are brought into the public's field of vision, as in 
the 1996 Copenhagen exhibition By the Light of the Crescent Moon. The Tate Gallery's 2008 Orientalist exhibition The Lure of the East did not display any of Jerichau-Baumann's works, allowing the French painter Henriette Browne to represent female harem paintings. Browne, like Jerichau-Baumann, was a much-celebrated foreign woman in the British art world in the 1860s, but there are also many British female Orientalists of the nineteenth century - such as Margaret Murray-Cookesley and Ethel Carrick - who are waiting to be rediscovered. The English translation of Jerichau-Baumann's "Egypt 1870" travelogue not only shows the multifaceted nature of this fascinating Polish-Danish artist - as commercial painter, artistic ethnographer, and fabulating travel writer - but it might perhaps also give Victorian and travel writing scholars and art historians an incentive to further uncover female representations of the nineteenth-century Orient.

The University of Hong Kong

\section{NOTES}

1. All biographical information collated from Clement, Christensen, Petteys, Steward, and Vammen.

2. In the most general sense, the genre of Orientalist art, which was pioneered by the French then developed by British and other European artists, refers to images of the life, history, and topography of the geographical area between Turkey, the Near East and the Arab peninsula, and North Africa.

3. It is worth mentioning that many of the Jerichau children became, like their parents, accomplished artists. A number of the Oriental landscape and architectural paintings of the Jerichaus's second son, Harald (1851-78), are reproduced in Motley Images of Travel (Jerichau-Baumann). The third son, Holger Hvidtfeldt (1861-1900), found favour with the Russian tsar family who financed many of his trips which brought forth impressionist landscape paintings that the academy called the work of a "true visionary.” A grandson, Jens Adolf Emil (1890-1916), became one of Denmark's best-known modernist painters, who befriended Picasso in early twentieth-century Paris.

\section{WORKS CITED}

Andersen, Hans Christian. "Jens Adolph Jerichau og Elisabeth Jerichau, født Baumann.” Folkekalender for Danmark 3 Aargang (1854): 80-91.

Bøgh, Nicolaj Seidelin. Elisabeth Jerichau-Baumann: En karakteristik. Kjøbenhavn: n.p., 1886.

Christensen, Charlotte. "Elisabeth Jerichau-Baumann." Dictionary of Women Artists. Ed. Delia Gaze. London: Fitzroy Dearborn, 1997. 737-39.

Clement, Clara Erskine. Women in the Fine Arts, from the Seventh Century B.C. to the Twentieth Century A.D. 1904. Project Gutenberg. Web. 15 January 2009.

"French and Flemish Exhibition." Art Journal (June 1866): 194.

Jerichau-Baumann, Elisabeth. Brogede Rejsebilleder. Kjøbenhavn: Thieles, 1881.

Lewis, Reina. Gendering Orientalism: Race, Femininity and Representation. London: Routledge, 1996.

—. "Women Orientalist Artists: Diversity, Ethnography, Interpretation." Women: A Cultural Review 6.1 (1995): 91-106.

"Minor Topics of the Month." Art Journal (December 1869): 382.

Montagu, Mary Wortley. “To Lady Mar, Pera, Constantinople, 10 March 1718.” Turkish Embassy Letters. Introduction Anita Desai. Ed. Malcolm Jack. London: Pickering, 1993. 113-20.

Oxfeldt, Elisabeth. Nordic Orientalism: Paris and the Cosmopolitan Imagination, 1800-1900. Copenhagen: Museum Tusculanum P, U of Copenhagen, 2005. 
Petteys, Chris. Dictionary of Women Artists: An International Dictionary of Women Artists born before 1900. Boston: Hall, 1985.

Roberts, Mary. "Contested Terrains: Women Orientalists and the Colonial Harem." Orientalism's Interlocutors: Painting, Architecture, Photography. Ed. Jill Beaulieu and Mary Roberts. Durham: Duke UP, 2002. 179-203.

_ . "Harem Portraiture: Elisabeth Jerichau-Baumann and the Egyptian Princess Nazli Hanım." Local/Global: Women Artists in the Nineteenth Century. Ed. Deborah Cherry and Janice Helland. Aldershot: Ashgate, 2006. 77-98.

Steward, Brian, and Mervyn Cutten. The Dictionary of Portrait Painters in Britain up to 1920. Woodbridge: Antique Collectors' Club, 1997.

Vammen, Tinne. "Elisabeth Jerichau Baumann (1819-1881)." Dansk Kvindebiografisk Leksikon. <http://www.kvinfo.dk/side/170/bio/827/>. Web. 15 January 2009.

Von Folsach, Birgitte. By the Light of the Crescent Moon: Images of the Near East in Danish Art and Literature, 1800-1875. Copenhagen: David Collection, 1996. Print.

"The Works of Madame Jerichau." Art Journal (June 1871): 165. 